\title{
Constructing Learning Results as Learning Object Through Open Learning System
}

\author{
Henry Praherdhiono \\ Faculty of Education, State University of Malang, Indonesia \\ henry.praherdhiono.fip@um.ac.id
}

\author{
Eka Pramono Adi \\ Faculty of Education, State University of Malang, Indonesia \\ ekatepum@gmail.com
}

\begin{abstract}
The idea of writing is to build a learning object from students' thoughts on the Massive Open Online Courses (MOOCs). Student work as a result of learning, more stored in the assignment folder in learning management system. The development research was conducted for 110 students divided into 3 classes. Research development of students learning object produces a flexibility, openess, and has the potential to construct a student scientific work by themselves or to other students. Student learning activities, resulting in a student learning experience that is constructed from graduate students gradually.
\end{abstract}

Keywords: massive open online courses, learning management system

\section{INTRODUCTION}

The Learning University has a unique meaning of learning as the most important part in the Universitas Negeri Malang (UM). The School of Teknologi Pendidikan (TEP) is both a course and a course of study that facilitates the realization of learning activities and building resources to have performance in learning (Januszewski and Molenda, 2013; Plomp and Ely, 1996; Seels and Richey, 1994). Teknologi Pendidikan has several domains that include development (Seels and Richey, 1994) in various aspects of learning.

Ability in conducting research development in some studies has a meaning of support from the technology support to The Learning University. The realization of support is the importance of learning design centered on learners (Lai, 2015). So the Department of Teknologi Pendidikan needs to develop a learning materials centered on the learners to support the occurrence of The Learning University at the Universitas Negeri Malang.

The courses in education and learning require the management of learning resources. Management of learning resources becomes a need for learners (Cervone, 2012; Parkes et al., 2015). Students need learning materials that can be arranged logically and systematically to build their scientific constructs (Mayer et al., 2001). The course in science has similarities with the management of information. Management of information systems is a form of company in providing services to its customers (Caione et al., 2016; Galliers and Leidner, 2014; Gorry and Scott Morton, 1971).

Based on the economic scope of the service, it provides the impact of trust to ensure its sustainability (Luo et al., 2014). It is different with the course is the focus problem not only in economics, but rather the management of an information system intended for audiences $(\mathrm{Pu}, 2014)$ in various fields such as education ( $\mathrm{Pu}, 2014)$, economics and business (Caione et al., 2016), electronics industry (Luo et al., 2014) and other vocational sectors. This indicates that Information System Management is a fertilizer a fairly strategic science. Students of Teknologi Pendidikan are students who have been exposed to information and communication technology. Students in the era of 2010 already have gadgets in their communication (Dias and Diniz, 2014).

Students' ability is not matched by knowledge of usage. Generally learners only have the ability to use only or even just have the ability to watch it (Vanderplank, 2016). Although this is an ironic condition, almost all universities have weak student problems in information management. Students still rely on lecturers or others to influence themselves in scientific development (Lai, 2015). So students' requires learning materials Courses to build students' knowledge of managing information in (Verbert and Duval, 2004) independently and autonomously.

Lecturers have often used techniques in assignment to strengthen learning. The paradigm of constructivism relies on learning environments for constructing learners' scholarship (Bandura, 1989, 2001; Brookings et al., 1996). But teachers are often trapped to keep all the tasks and not be used as a learning object for other students. Learning object of student construction result can be used as study material for other student and student itself (Shroff et al., 2011). Teachers often build an opinion that learning outcomes only cease to be used at the end of the course. So students can not be a continuous inspiration (Gog and Sweller, 2015). Lectures become constant and continuously present the same thing without any change in the presentation.

Teachers need a systematic learning object learning, so as to encourage learners to constantly change. Teachers find it difficult to avoid a continuous development of scholarship. The course requires good learning object management. Content management system that has been common is Content Management System. Learning content needs to be built using appropriate scientific rules (Gog and Sweller, 2015, 2015; Mayer et al., 2001).

Learning management technology has the ability to manage learning in order to have easy access (Galliers and Leidner, 2014). Internet technology has experienced tremendous growth (Broadbent and Poon, 2015; Parkes et al., 2015). Various areas of study mention that the Internet is a medium that has a high flexibility to be a technology partner in the field of education (O'Flaherty and Phillips, 2015). Internetbuilt interconnections cause learning objects to be more 
easily accessible from cloud storage (Tsai and Shen, 2015). Storage in the cloud storage facilitates learning materials entered and accessed with the help of the internet.

The development of scientific learning technology has led to technology-friendly learners. Learning technology has been able to facilitate learning and learning (Dias and Diniz, 2014; White, 2015). Students are entities that benefit in the development of scientific learning technology. Learners can access learning resources whenever and wherever as easily as the use of a wiki database (Choy and $\mathrm{Ng}$, 2007). when compared with access to learning resources in the year 90'an will appear some easy access to learning resources such as the presence of cloud computing (Tsai and Shen, 2015), the presencelearning object (Cervone, 2012), several open source learning MOOC (Hew and Cheung, 2014) which is spread and can be accessed through the Internet with ease (Kuo et al., 2014).

Stored in a digital format will be easily accessible if the storage is put into the learning management system. So in this learning and learning era, teachers and lecturers need to manage student learning outcomes prepared as open learning object for other students (Gog and Sweller, 2015; Hew and Cheung, 2014; Shroff et al., 2011).

Learning objects that have flexible and open characteristics are the development of educational technology research umbrella in order to facilitate learning and learning (Januszewski and Molenda, 2013, Plomp and Ely, 1996; Seels and Richey, 1994; Yaniv, 2008). Flexible and open education material is a learning object that has the ability to reach up to student self-tools (Afreen, 2014; Burns-Sardone, 2014; Kong and Song, 2015). So that students get learning objects with flexible and open characteristics, and can reduce and facilitate access to content (Cervone, 2012; Margaryan et al., 2015; Verbert and Duval, 2004).

\section{RESEARCH AND DEVELOPMENT METHODS}

Methods Development of web-based learning has phases of development among other things: (1) analysis; (2) evaluation plan; and (3) concurrent phases covering design, system development, testing and implementation and formative evaluation. Method Development Application development Learning object using web-based learning development, with the following stages:

\section{Analysis}

The analysis process includes two fese of problem analysis 1) why learners need the formation of learning object by giving questions about learning object that has been read (Q1) and 2) component analysis of learning object formation with meberi question what components are needed (Q2) (DavidsonShivers, 2009; Davidson-Shivers and Rasmussen, 2006).

\section{Evaluation Design}

The web developer, in this case the researcher, determines the formative evaluation instrument on learning for whether the application of learning object management can be used by the learners . The design of evaluation in the form of questions about leraning object (Q3).

\section{Concurrent Design}

Concurrent design is an activity to develop the system as a whole. Development activities with each other is a series of interplay (Davidson-Shivers, 2009). The linked design has several steps and processes, including:

\section{Activity planning}

The planning stage of activity in process drawings is not illustrated as it is only the stage that initiates the design process.

\section{Design Process}

In the design process carried out the investigation of object sepesifikasi, making a draft assessmentmen, or better known as the Task Objective Assessment Item Blueprint (TOAB). Grouping blueprint that tops are examples of assessment, step learning process, user data, models of learning and learning strategies. The second Blueprint is the learning orientation, the delivery model and the learning content, the measurement of the learning process, the conclusion and the cover.

\section{Development Process}

Development process can not be separated from the testing process, formative evaluation and design process. This process is the activity of the formation of learning products. To be a product that is considered good, the development process is done more than once. This means that other processes also experience repetition.

\section{RESULT AND DISCUSSION}

Students as a community of information users have an ever-increasing ability every day to strengthen in expressing the profile of thinking and producing individual capacities that depend on effective educational information systems. In the Q1 group, students present which learning objects are viewed. One of the only question in Q1 there is in figure 1. Failure learners only read the learning object released by the group on their own social media and less reading learning objects from countries countries other. So some students study in a superficial taxonomy, memorizers and listeners in real-life situations as fact conditions are corroborated also by other researchers (Barrow, 1990; Caione et al., 2016; Galliers and Leidner, 2014; Lai, 2015). In addition, in learning and learning is not expected to realize the transformation and production of information in society including this individual who is misguided even hoax (Pu, 2014). 

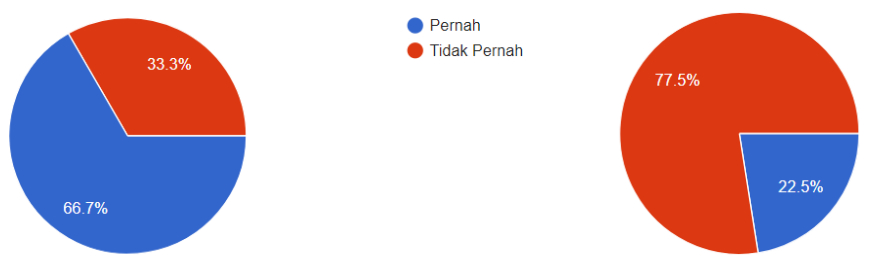

Pernah

Class A: 30 respondents Class B: 40 respondents

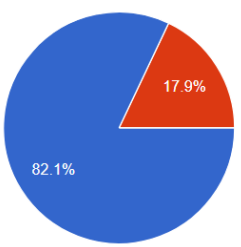

Pernah

Class C: 40 respondents

Figure 1

Student Activity Data View Learning Object from Abroad

Learners already have tools capable of accessing learning objects. In Q2 result, students have had the devices one of the only question is contained in Figure 2. The learners have been able to connect new information and skills by comparing the new information and the old skills. So learning object is no longer controlled by the teachers, but had to rely on themselves and participate, thinkingline with research Parkes et al., (2015), research has been able to find indicators of effective educational use of learning objects (Brennan, 2013; O 'Flaherty and Phillips, 2015; Tsai and Shen, 2015). Effective education can be realized with different approaches in accordance with technological developments, expectations, and community needs. When considered from this point of view, focusing on learner education is a significant and accepted approach in recent years.
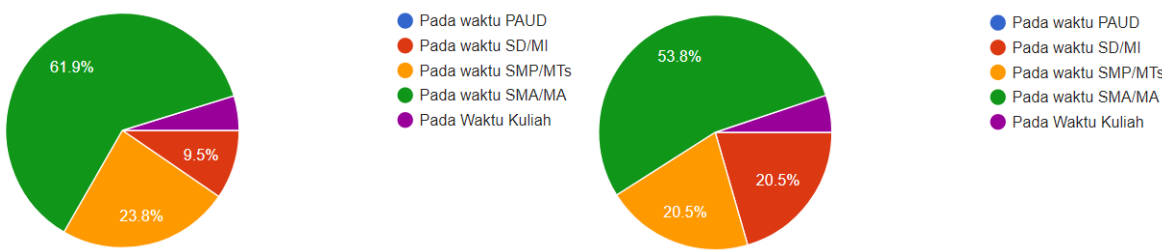

Class A: 30 Respondents Class B : 40 respondents

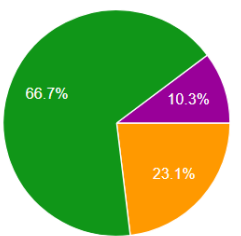

- Pada waktu PAUD - Pada waktu SDMMI Pada waktu SMP/MTs - Pada waktu SMA/MA - Pada Waktu Kuliah

Class C: 40 respondents

Figure 2

Smartphone Ownership Data by Age

Capacity learning through learning objects can be constructed through an open web-based learning system. This is because, education-centered learners is a very effective phenomenon to make students as an information society. In this approach, individual development, learning and learning and the active participation of learners are essentially capable of enhancing contextual thinking (Horvat et al., 2015). Learning objects prioritizing assignments and student studies are one of the principles of the approach (Beckers et al., 2016).

Education centered on learners (Hannafin et al., 2014); the period of education for individuals who have the skills of scientific thinking (Button et al.,
2014), has been learning to learn, productive, able to reach the information and using it, have communication skills, and have adopted universal values, using technology effectively and had realizing itself is a reconstruction that will supply learners' participation at every stage (Shroff et al., 2011). As can be seen from the above definition, learners not only learn and listen but also participate actively and responsibly (Wang, 2014). Learners learn through questioning and discovering. Too, learners gain experience in both individual and group work (Chang and Chen, 2009). Furthermore, learners can apply what learners have learned in a learning environment with real-life conditions (Parkes et al., 2015). 


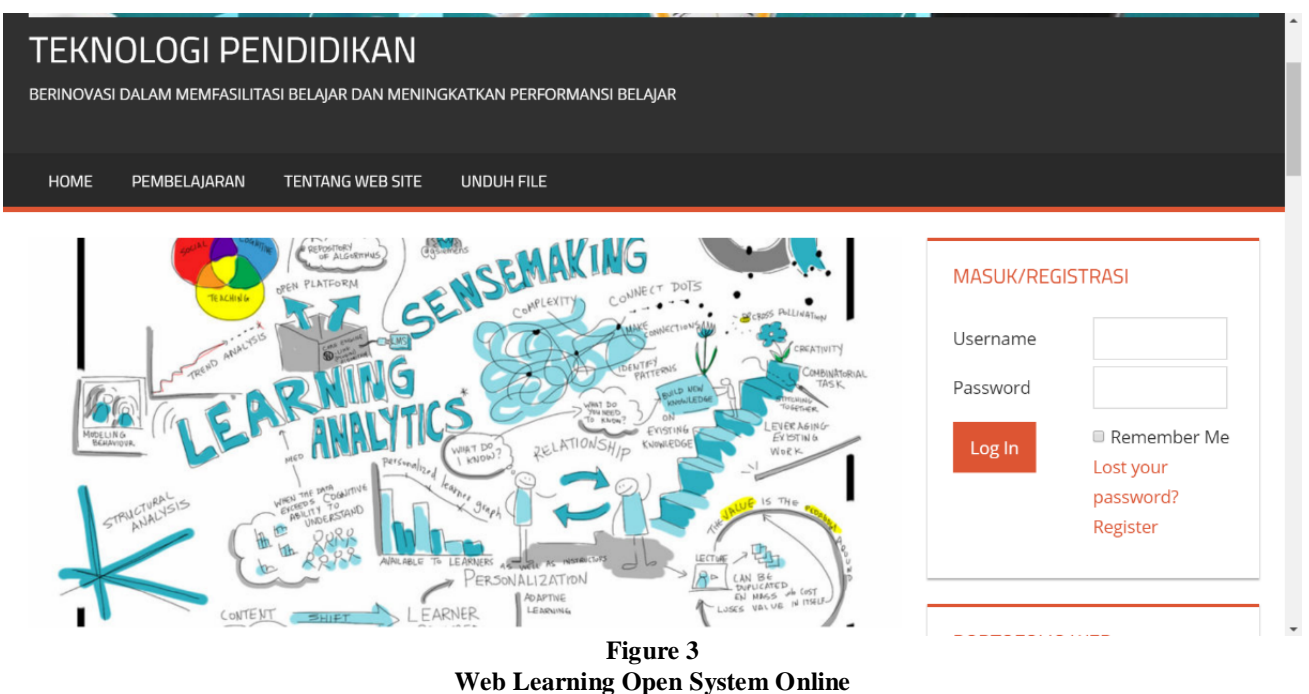

The ability of students in building knowledge with open learning system is good. In picture 5 as one of the questions in Q3 has proven the students can contribute in building the scholarship. Information and communication technology is one of the significant contributors of the learner centered approach (Hannafin et al., 2014; Nistor et al., 2015). Students use smartphones, computers, show data, modems, iPods and tablets, and also with technological tools like the internet. This condition is definitely a feature of the $\mathrm{z}$ generation or the net generation.
This is in line with some research that some gadgets have begun to be exploited (Broadbent and Poon, 2015). Conditions encountered are, lecturers no longer need to make the introduction of the internet in learning, because some learning tools have shifted to electronic versions. As d is defined as a large collection of learning objects from student learning outcomes and studies. The development of information and communication encourages students to make access to learning objects easily (Britten and Mullen, 2003; Edwards, 2016; Tosun and Bariş, 2011).

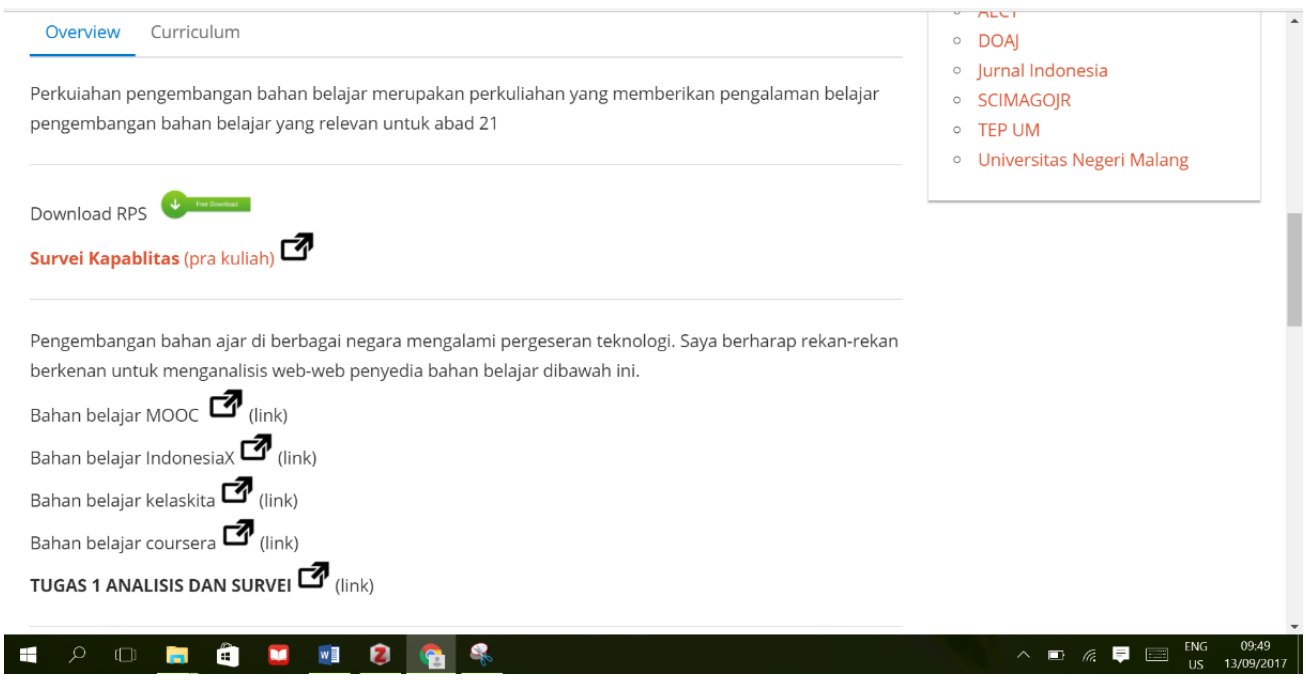

Figure 4

Presentation of the Course Openly

MOOCs technology is also known as the new round of Electronic business. Development in information and communication technology, the increasing number of users in technology, the adaptability of a new generation for this technology has facilitated the use of MOOCs, e-portfolio (Beckers et al., 2016; Shroff et al., 2011). MOOCs, e-portfolios,
CMS and LMS are foreseen to be used in the coming years as an integral part of education have been used both as educational tools and evaluation materials in many countries. With the development of educational technology infrastructure, improved applications will enable educational approach centered on learners to improve. 


\section{Buku 1 Jelaskan Learning objects Resources for learning worldwide}

Bab ini menjelaskan kebutuhan untuk mempelajari objek (LO) dan pentingnya berbagi,

dan kemudian menawarkan definisi LO yang diambil dari deskripsi kebutuhan itu.

Learning object resource for learning menjelaskan kebutuhan untuk mempelajari objek (LO) dan pentingnya berbagi, dan kemudian menawarkan definisi LO yang diambil dari deskripsi kebutuhan itu.

Berguling Napster dan cari jalan untuk Learnster. Dengan kemunculan yang baru spesifikasi metadata yang diakui secara internasional, pertukaran pelajaran dan kursus oleh peserta didik, instruktur dan pengembang kursus. Dengan membayangkan memiliki akses tanpa batas ke toko sumber belajar yang luas seperti animasi, video, simulasi, permainan edukasi, dan teks multimedia dengan cara yang sama seperti pengguna Napster memiliki akses ke file musik Learning objects (LOS) inilah yang membuat ini terjadi. LO terkadang didefinisikan sebagai sumber pendidikan yang dapat digunakan di pembelajaran yang didukung teknologi. Dengan deskripsi yang tepat, mereka bisa menjadi unit modular yang bisa dirakit bersama untuk membentuk pelajaran dan kursus. LO bisa berdasarkan teks elektronik, simulasi, situs web, gambar grafis gif, Quicktime film, applet Java atau sumber lain yang bisa digunakan dalam belajar.

Learning objects Resources for learning worldwide adalah bagian yang lebih lengkap dalam dunia pendidikan untuk institusi pembelajaran diseluruh dunia. dan object sumber belajar ini menjadi sangat instan karena dapat diakses dari

melalui internet dan semakin memudahkan untuk pengajaran dan pembelajaran.

Learning objects resources for learning worldwide objek yang digunakan untuk mendukung pembelajaran digital

Figure 5

The Ability of Students to use Learning Objects of Other Students

\section{CONCLUSION}

The development of web-based learning has led to a new era. Although research is still dependent on the advantages and disadvantages of using electronic devices, but for learners ithas benefited to construct scholarship. In detail some studies have also demonstrated the benefits of open learning, have been mentioned in previous studies and have also described the concept of MOOCs and e-portfolios, the differences and similarities between them shown. The presentation of learning objects developed by the students themselves has drawn the benefits of using how to realize the construction of scholarship for students (Beckers et al., 2016; Brennan, 2013; Britten and Mullen, 2003; TOSUN and BARIŞ, 2011; Tubaishat, 2014). Thus, it aims to form the basis for the concept of learning object and explain that the learning object developed by the students themselves can be used in different format and flexible in education. In accordance with the objective, this research will be important for improving the learning performance of learners. The main effort adalam This article was success build learning objects from the ideas of students on Massive Open Online Courses (MOOCs). Besides Research development pursuitWeb-based learning object produces a flexible, open, and has the potential to construct a science student creators themselves or to other students.

\section{REFERENCES}

[1] Afreen, R. 2014. B Ring Your Own Device (BYOD) in Higher Education: Opportunities and Challenges. Int. J. Emerg . Trends Technol. Comput. Sci., 3, 233-236.

[2] Bandura, A. 2001. Social Cognitive Theory: An Agentic Perspective. Annu. Rev. Psychol., 52, 1-26.
[3] Bandura, A. 1989. Human Agency in Social Cognitive Theory. Am. Psychol., 44, 1175.

[4] Barrow, C. 1990. Implementing an Executive Information System: Seven Steps for Success. Inf. Syst. Manag., 7, 41-46.

[5] Beckers, J., Dolmans, D., and VanMerriënboer, J. 2016. e-Portfolios Enhancing Students' Self-directed Learning: A Systematic Review of Influencing Factors. Australas. J. Educ. Technol., 32, 2.

[6] Brennan, R. L. 2013. A Multivariate Generalizability Analysis of the Portfolio Assessments in Dental Education. New York: CASMA Research Report Series.

[7] Britten, J. S., and Mullen, L. J. 2003. Interdisciplinary Digital Portfolio Assessment: Creating Tools for Teacher Education. J. Inf. Technol. Educ., 2, 41-50.

[8] Broadbent, J., Poon, WL, 2015. Self-regulated Learning Strategies \& Academic Achievement in Online Higher Education Learning Environments: A Systematic Review. Internet High. Educ., 27, 1-13.

[9] Brookings, J. B., Wilson, G. F., Swain, C. R. 1996. Psychophysiological Responses to Changes in Workload During Simulated Air Traffic Control. Biol. Psychol., 42, 361-377.

[10] Burns-Sardone, N. 2014. Making the Case for BYOD Instruction in Teacher Education. Issues Informing Sci. Inf. Technol., 11, 192-200.

[11] Caione, A., Guido, A. L., Martella, A., Paiano, R., and Pandurino, A., 2016. Knowledge Base Support for Dynamic Information System Management. Inf. Syst. E-Bus. Manag., 14, 533-576.

[12] Cervone , H. F. 2012. Digital Learning Object Repositories. OCLC Syst. Serv. Int. Digits. Libr. Perspect., 28, 14-16.

[13] Chang, T. Y., and Chen, Y. T. 2009. Cooperative Learning in E-learning: A Peer Assessment of StudentCentered using Consistent Fuzzy Preference. Expert Syst. Appl., 36, 8342-8349. 
[14] Choy, S. O. 2007. Implementing a Wiki Software for Supplementing Online Learning. Australas. J. Educ. Technol., 23.

[15] Davidson-Shivers, G. V. 2009. Frequency and Types of Instructors Interactions in Online Instruction. $J$. Interact. Online Learn., 8, 23-40.

[16] Davidson-Shivers, G.V. and Rasmussen, KL, 2006. Web-based Learning: Design, Implementation, and Evaluation. Prentice Hall.

[17] Dias, S. B., and Diniz, J. A. 2014. Towards an Enhanced Learning Management System for Blended Learning in Higher Education Incorporating Distinct Learners' Profiles. Educ. Technol. Soc., 17, 307-319.

[18] Edwards, R. 2016. Collaborative Use of an e-portfolio: How students Managed the Process. There Back Charting Flex. Pathw. Open Mob. Distance Educ., 35.

[19] Galliers, R. D. and Leidner, D. E. 2014. Strategic Information Management: Challenges and Strategies in Managing Information Systems. New York: Routledge.

[20] Gog, T. and Sweller, J. 2015. Not Only, But More than That, The Testing Effect Decreases or Even Disappears as The Complexity of Learning Materials Increases. Educ. Psychol. Rev., 27, 247-264.

[21] Gorry, G. A., Scott Morton, M. S. 1971. A Framework for Management Information Systems. New York: Longman.

[22] Hannafin, M. J., Hill, J.R., Land, S.M., and Lee, E. 2014. Student-Centered, Open Learning Environments: Research, Theory, and Practice. New York: Springer.

[23] Hew, K. F., Cheung, W. S., 2014. Students 'and Instructors' use of Massive Open Online Courses (MOOCs): Motivations and Challenges. Educ. Res. Rev., 12, 45-58.

[24] Horvat, A., Dobrota, M., Krsmanovic, M., and Cudanov, M., 2015. Student Perception of Moodle Learning Management System: A Satisfaction and Significance Analysis. Interact. Learn. Environ., 23 , 515-527.

[25] Januszewski, A., and Molenda, M. 2013. Educational Technology: A Definition with Commentary. New York: Routledge.

[26] Kong, S. C., and Song, Y., 2015. An Experience of Personalized Learning Hub Initiative Embedding BYOD for Reflective Engagement in Higher Education. Comput . Educ., 88, 227-240.

[27] Kuo, Y. C., Walker, A. E., Schroder, K. E., Belland, B. R., 2014. Interaction, Internet Self-efficacy, and Selfregulated Learning as Predictors of Student Satisfaction in Online Education Courses. Internet High. Educ., 20, $35-50$.

[28] Lai, C. 2015. Modeling Teachers 'Influence on Learners' Self-directed use of Technology for Language Learning Outside the Classroom. Comput. Educ., 82, 74-83.

[29] Luo, Y., Zhang, S., Wan, S., and Deng, R. 2014. Analysis and Design of Information Management Systems for Defective Automobile Products Recall. Appl. Mech. Mater., 494, 250.

[30] Margaryan, A., Bianco, M., and Littlejohn, A., 2015. Instructional Quality of Massive Open Online Courses (MOOCs). Comput. Educ., 80, 77-83.

[31] Mayer, R. E., Heiser, J., and Lonn, S. 2001. Cognitive Constraints on Multimedia Learning: When Presenting more Material Results in Less Understanding. J. Educ. Psychol., 93, 187.

[32] Nistor , N., Trăuşan-Matu, Ş., Dascălu, M., Duttweiler, H., Chiru, C., Baltes, B., and Smeaton, G. 2015. Finding Open Student-Centered Learning Environments on the Internet: Automated Dialogue
Assessment in Academic Virtual Communities of Practice. Comput. Hum. Behav., 47, 119-127.

[33] O'Flaherty, J., and Phillips, C. 2015. The Use of Flipped Classrooms in Higher Education: A Scoping Review. Internet High. Educ., 25, 85-95.

[34] Parkes, M., Stein, S., and Reading, C. 2015. Student Preparedness for University e-learning Environments. Internet High. Educ., 25, 1-10.

[35] Plomp, T., and Ely, D. P. 1996. International Encyclopedia of Educational Technology. New York: ERIC.

[36] $\mathrm{Pu}$, J. 2014. Information Systems Management on Concepts-Reasoning of Preschool Education Field: Independent Learning. Paper 3rd International Conference on Science and Social Research (ICSSR 2014). Atlantis Press.

[37] Seels, B. and Richey, R. C. 1994. Instructional Technology. New York: Bloomingt. Assoc. Educ. Commun. Technol.

[38] Shroff, R. H., and Deneen, C. C. 2011. Analysis of the Technology Acceptance Model in Examining Students' Behavioral Intention to use an e-portfolio System. Australas. J. Educ. Technol., 27.

[39] TOSUN, APDN, BARIŞ, TMF. 2011. E-Portfolio Applications in Education. Online J. New.

[40] Tsai, C. W., and Shen, P. D. 2015. Do Really Improve Students' Learning? Cloud Technology: Concepts, Methodologies, Tools, and Applications. IGI Global, 2126-2134.

[41] Tubaishat, A. 2014. E-portfolio Assessment for Learning: Ten Years Later-An Experience from an Outcome-Based University. Int. J. Adv. Comput. Sci. Inf. Technol. IJACSIT, 3, 368-378.

[42] Vanderplank, R. 2016. 'Effects of' and 'Effects with' Captions: How Exactly does Watching a TV Programming with Same-Language Subtitles Make a Difference to Language Learners? Lang. Teach., 49, 235-250.

[43] Verbert , K., and Duval, E. 2004. A Comparative Analysis of Learning Objects Content Models. Proceedings of the EDMEDIA 2004 World Conference on Educational Multimedia, Hypermedia and Telecommunications.

[44] Wang, T. H. 2014. Developing an AssessmentCentered e-Learning System for Improving Student Learning Effectiveness. Comput. Educ., 73, 189-203.

[45] White, D. L. 2015. Gatekeepers to Millennial Careers: Teachers Who Adopt Technology in Education. Handb. Mob. Teach. Learn., 1-10.

[46] Yaniv, H., 2008. Development of Learning Resources to Promote Knowledge Sharing in Problem Based Learning. Manag. J. Educ. Technol., 5, 15. 